\title{
State of the art review in gonadal dysgenesis: challenges in diagnosis and management
}

\author{
Bonnie McCann-Crosby ${ }^{1 *}$, Roshanak Mansouri ${ }^{2}$, Jennifer E Dietrich ${ }^{2}$, Laurence B McCullough ${ }^{3}$, V Reid Sutton ${ }^{4}$, \\ Elise G Austin ${ }^{4}$, Bruce Schlomer ${ }^{5}$, David R Roth ${ }^{5}$, Lefkothea Karaviti ${ }^{1}$, Sheila Gunn ${ }^{1}$, M John Hicks ${ }^{6}$ \\ and Charles G Macias ${ }^{7}$
}

\begin{abstract}
Gonadal dysgenesis, a condition in which gonadal development is interrupted leading to gonadal dysfunction, is a unique subset of disorders of sexual development (DSD) that encompasses a wide spectrum of phenotypes ranging from normally virilized males to slightly undervirilized males, ambiguous phenotype, and normal phenotypic females. It presents specific challenges in diagnostic work-up and management. In XY gonadal dysgenesis, the presence of a $Y$ chromosome or $Y$-chromosome material renders the patient at increased risk for developing gonadal malignancy. No universally accepted guidelines exist for identifying the risk of developing a malignancy or for determining either the timing or necessity of performing a gonadectomy in patients with XY gonadal dysgenesis. Our goal was to evaluate the literature and develop evidence-based medicine guidelines with respect to the diagnostic work-up and management of patients with XY gonadal dysgenesis. We reviewed the published literature and used the Grading of Recommendation, Assessment, Development, and Evaluation (GRADE) system when appropriate to grade the evidence and to provide recommendations for the diagnostic work-up, malignancy risk stratification, timing or necessity of gonadectomy, role of gonadal biopsy, and ethical considerations for performing a gonadectomy. Individualized health care is needed for patients with XY gonadal dysgenesis, and the decisions regarding gonadectomy should be tailored to each patient based on the underlying diagnosis and risk of malignancy. Our recommendations, based on the evidence available, add an important component to the diagnostic and management armament of physicians who treat patients with these conditions.
\end{abstract}

Keywords: XY gonadal dysgenesis, Complete gonadal dysgenesis, Partial gonadal dysgenesis, Gonadectomy, Gonadal biopsy, Gonadoblastoma, Dysgerminoma, Carcinoma in situ, Malignancy risk, Ethics

\section{Introduction}

Gonadal dysgenesis is a term used for a unique subset of disorders of sexual development (DSD) [1] characterized by incomplete or defective formation of the gonads (ovary or testis) due to either structural or numerical anomalies of the sex chromosomes or mutations in the genes involved in the development of the gonad [2]. Dysgenetic gonads are characterized by variable degrees of immaturity or dysfunction, which can manifest in a wide range of genital ambiguity. Gonadal dysgenesis can be classified as either complete (CGD) or partial (PGD) depending on the gonadal morphology [3,4]. In CGD

\footnotetext{
* Correspondence: mccann@bcm.edu

'Division of Pediatric Endocrinology, Baylor College of Medicine, Texas Children's Hospital, Houston, TX 77030, USA

Full list of author information is available at the end of the article
}

(i.e., 46,XY Swyer syndrome), no gonadal development occurs, and, as a consequence, patients have a completely female phenotype due to the lack of any gonadal steroid production. In PGD in which a Y chromosome is present, there is incomplete testis determination and the external phenotype depends on the degree of testicular function. The most common karyotype seen in PGD is $45, \mathrm{X} / 46, \mathrm{XY}$, but 46,XY and other forms of mosaicism involving the $\mathrm{Y}$ chromosome also can be seen.

Patients with gonadal dysgenesis who have a Y chromosome or Y-chromosome material are at increased risk for developing germ cell tumors such as gonadoblastoma or carcinoma in situ (CIS), with the potential for malignant transformation to dysgerminoma or seminoma, respectively [5-7]. The term gonadoblastoma was first introduced by Scully in 1953 and is the most common germ cell 
tumor seen in patients with XY gonadal dysgenesis [8]. A benign germ cell ovarian neoplasm composed of germ cells and sex cord stromal cells, a gonadoblastoma almost always arises from a dysgenetic gonad with a Y chromosome [9]. Gonadoblastoma usually presents in the second decade, but cases occurring in early infancy have been reported [10]. In 50-60\% of cases, gonadoblastomas are associated with malignant germ cell tumors, most commonly dysgerminomas. The prognosis is favorable when the gonadoblastoma is associated with dysgerminoma, but unfavorable when associated with other germ cell tumors including yolk sac tumors, seminomas, immature teratomas, embryonal carcinomas, or choriocarcinomas [11]. CIS, otherwise known as intratubular germ cell neoplasia unclassified, is the common precursor for testicular germ cell tumors including seminomas, embyronal carcinomas, teratomas, and yolk cell tumors [6]. Gonadal dysgenesis is a known risk factor for CIS [12]. The natural history of untreated CIS is a $40 \%$ estimated risk of progression to invasive cancer within three years and a $50 \%$ estimated risk of progression within five years [13].

To prevent the development of malignancy in patients with XY gonadal dysgenesis, gonadectomy typically is recommended, but debate ensues concerning which patients require surgery and the appropriate timing [14]. Further, no standard approach or guidelines have been established for the diagnostic workup and management of these patients. The objective of this paper was to review the existing evidence and to provide recommendations for the appropriate diagnostic work-up and timing of performing a gonadectomy in the patient with XY CGD or XY PGD. We reviewed which patients require gonadectomy, factors involved in the risk of developing a malignancy, and ethical considerations with respect to gonadectomy. We used the Grading of Recommendation, Assessment, Development, and Evaluation (GRADE) system when appropriate to grade the evidence and provide recommendations. The GRADE system is an evidence-based medicine tool used to evaluate the quality of the evidence and the strength of recommendations [15]. We provide herein both a review of the literature and guidelines for endocrinologists, gynecologists, ethicists, psychologists, urologists, and geneticists who care for patients with XY gonadal dysgenesis, with the intent that this approach will be relevant for the standardization of the field in the upcoming years.

\section{Methods}

We identified two clinically relevant questions to be answered from the evidence for diagnosis and management of patients with XY CGD or XY PGD:

1. In patients with suspected XY gonadal dysgenesis, what diagnostic testing should be considered to establish the diagnosis?
2. Which patients with XY gonadal dysgenesis require gonadectomy, and what is the appropriate timing?

Sub-questions identified were:

a. What are differences in risks of malignancy based on diagnoses?

b. Is there a role for gonadal biopsy?

c. What ethical considerations must be taken into account before undertaking a gonadectomy?

To answer these questions, databases were searched for research-based articles on infants, children, and adults with XY CGD or XY PGD. The databases included Pub Med, Cochrane Collaboration, and Google Scholar. We included only articles published in English and no earlier than 1970, as prior to this date the literature in this area consists of mainly case reports and no large case series. Specific keywords and terms used included: complete or pure gonadal dysgenesis, mixed or partial gonadal dysgenesis, XY gonadal dysgenesis, diagnosis, gonadectomy, gonadoblastoma, dysgerminoma, malignancy risk, gonadal biopsy, and ethics.

We searched the literature specifically for articles that addressed each question. The GRADE system was used when applicable. The quality of the evidence was evaluated as "very-low quality", "low quality", "moderate quality", or "high quality". The recommendations provided were either "strong" or "weak". For questions for which the GRADE system did not apply, a consensus statement was formulated.

\section{Evidence and recommendations}

Our search of the major databases yielded articles addressing each question. Overall, the search yielded consensus statements, observational studies, case reports, personal experience, and review articles. No randomized controlled trials were identified. The evidence and recommendations for each question are described below:

\section{Question 1: in patients with suspected $X Y$ gonadal dysgenesis, what diagnostic testing should be considered to establish the diagnosis? \\ Evidence}

The search yielded three review articles and several case reports that provided recommendations for the diagnostic work-up of gonadal dysgenesis. The review articles were by Ostrer [3], Fleming and Vilain [16], and Michala and Creighton [17]. Because they are review articles, the GRADE tool could not be applied. According to these reviews, the diagnosis of $\mathrm{XY}$ gonadal dysgenesis is established based on physical examination, hormonal evaluation, imaging studies, genetic studies 
including karyotype, and gonadal histology (see discussion below and Figures 1 and 2). As there are differences between the clinical findings in XY CGD and XY PGD, each will be discussed separately.

\section{Complete (pure) XY gonadal dysgenesis (XY CGD)}

Patients with 46,XY CGD, or Swyer syndrome, are phenotypically female with normal Müllerian structures and bilateral streak gonads [18]. They most commonly

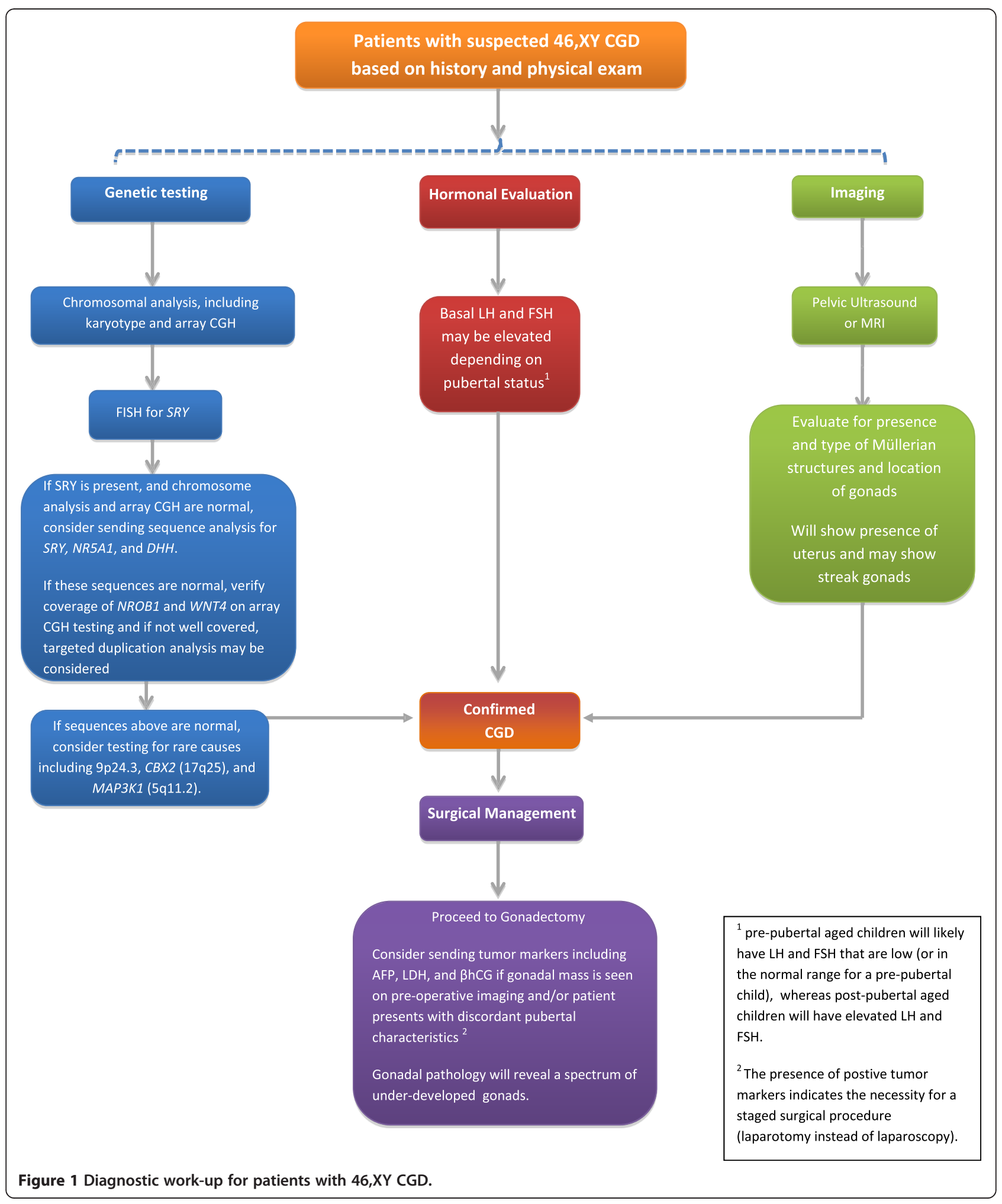




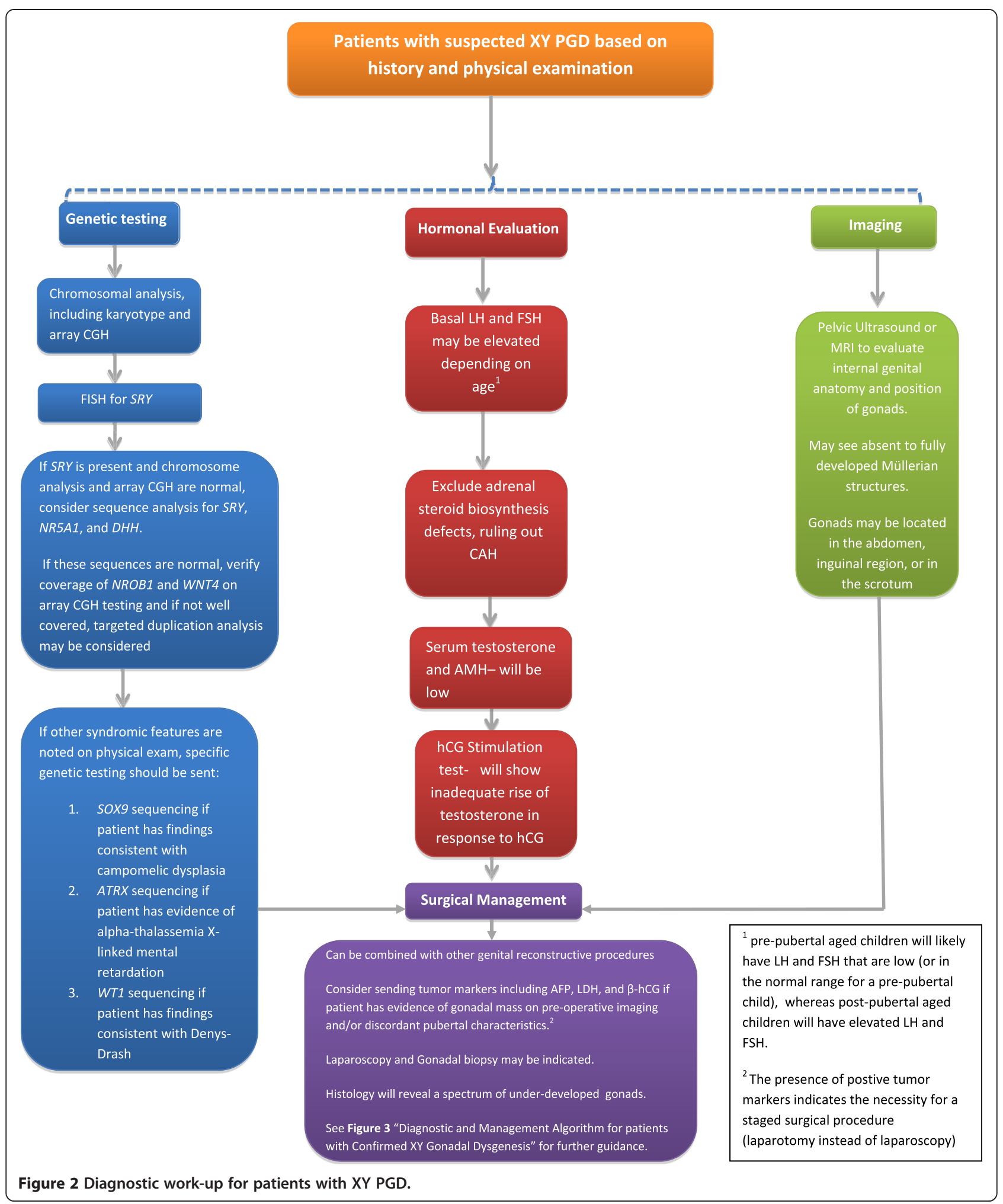

present in adolescence with delayed puberty or primary amenorrhea due to their non-functional gonads. Physical exam reveals normal female external genitalia. Endocrine evaluation usually shows hypergonadotropic hypogonadism with elevated basal LH and FSH, as the gonads are not functional. Imaging studies, including pelvic ultrasound or MRI, demonstrate the presence of a uterus and may show bilateral streak gonads. If gonadectomy or 
gonadal biopsy is performed, gonadal histology reveals the presence of bilateral dysgenetic streak gonads. Tumor markers including AFP, $\beta$-hCG, and LDH are known to be associated with germ cell malignancy. Although the evidence for routinely sending serum tumor markers for screening purposes in patients with XY CGD is lacking, positive tumor markers in the setting of a gonadal mass on pre-operative imaging and/or discordant pubertal characteristics (i.e., precocious puberty or virilization) suggests that a staged surgical procedure is necessary [19]. Finally, chromosomal analysis reveals a 46,XY karyotype. Mutations and deletions in the SRY (sex-determining gene on the $\mathrm{Y}$ chromosome) have been reported in the literature to account for $10-20 \%$ of the cases of $46, \mathrm{XY}$ CGD $[17,20]$. Other mutations identified have included NR5A1 (9q33) [16,20,21], DHH (12q13.1) [3,20], NROB1 (DAX 1) [3,16], WNT4 [3,16], DMRT1 (9p24.3) deletion [3,16,22], CBX2 (17q25) deletion [23], and a heterozygous mutation in MAP3K1 (5q11.2) [24]. In many cases, the cause of XY CGD remains unknown.

\section{Recommendations}

For patients with suspected XY CGD, we recommend the following testing to establish the diagnosis (see Figure 1):

a. Physical examination: including genitourinary exam to assess for clitoromegaly, phallic size, hypospadias, presence of palpable gonads either in the labioscrotal fold or inguinal region and to evaluate the introitus and patency of the vagina and for other dysmorphic features/malformations that may indicate an underlying syndrome.

b. Genetic testing (adapted from Ostrer [3]):

i. Chromosomal analysis, including karyotype and array $\mathrm{CGH}$

ii. FISH for SRY. Patients with Turner's syndrome and a 45,X karyotype require FISH for SRY to evaluate for cryptic Y mosaicism [32].

iii. If $S R Y$ is present and chromosome analysis and array $\mathrm{CGH}$ are normal, consider sequence analysis for $S R Y, N R 5 A 1$, and $D H H$. If these sequences are normal, verify coverage of $N R O B 1$ and WNT4 on array CGH testing and if not well covered, consider targeted duplication analysis.

iv. If other syndrome features are noted on examination, specific genetic testing should be sent

1. SOX9 sequencing if patient has findings consistent with campomelic dysplasia

2. ATRX sequencing if patient has evidence of alpha-thalassemia X-linked mental retardation

3. WT1 sequencing if patient has findings consistent with Denys-Drash syndrome

c. Hormonal evaluation i. Basal LH and FSH

ii. Serum testosterone levels

iii. hCG stimulation test

iv. Anti-Müllerian Hormone

v. Exclude adrenal steroid biosynthesis defects

d. Imaging: pelvic ultrasound or MRI to look for internal genital anatomy and gonad position; may not be able to visualize undescended gonads on imaging.

e. Surgical management: laparoscopy and gonadal biopsy may be indicated. If the patient has a gonadal mass on pre-operative imaging and/or discordant pubertal characteristics, consider serum tumor markers, including AFP, LDH, and beta-hCG, for preoperative planning. If tumor markers are positive, a staged surgical procedure (laparotomy instead of laparoscopy) is indicated.

\section{Evidence quality: low}

Strength of Recommendation: Strong for all categories except sections iii and iv of the genetic testing section and routinely sending serum tumor markers, which are weak recommendations.

\section{Partial XY gonadal dysgenesis (PGD)}

$X Y$ PGD includes a heterogeneous group of individuals with varying degrees of clinical phenotypes and various karyotypes. Included in this group are patients with Turner syndrome who have a mosaic karyotype, usually $45, \mathrm{X} / 46, \mathrm{XY}$. The most common karyotype of patients with $\mathrm{XY}$ PGD is $45, \mathrm{X} / 46, \mathrm{XY}$, but others may have $46, \mathrm{XY}$ or $45, \mathrm{X} / 47, \mathrm{XYY}$. Patients can have a spectrum of presentations, including females with a Turner syndrome phenotype, ambiguous genitalia, under-virilized males, or normal phenotypic males [25]. Phenotypically normal males with $45, \mathrm{X} / 46, \mathrm{XY}$ may not be diagnosed unless they are evaluated in adulthood for infertility secondary to reduced sperm production from dysgenetic testes [26]. Imaging shows absent to fully developed Müllerian structures, depending on the degree of testicular dysgenesis. Gonadal histology may reveal either bilateral dysgenetic testes or one streak gonad and a contralateral dysgenetic or normal-appearing testis. As seen in patients with $\mathrm{XY}$ CGD, patients with XY PGD often show evidence of hypergonadotropic hypogonadism with elevated basal LH and FSH levels at the age when puberty normally occurs. Patients with PGD have been shown to have a diphasic pattern of $\mathrm{LH}$ and FSH secretion whereby gonadotropin concentrations are significantly elevated during infancy, fall to nearly normal values during childhood, and return to significantly elevated levels after the normal age of puberty $[27,28]$. Measurements of serum testosterone and anti-Müllerian hormone (AMH) usually are decreased, and human chorionic gonadotropin (hCG) stimulation 
testing usually shows minimal to no elevation in testosterone levels in response to hCG. The evidence for routinely sending serum tumor markers such as AFP, LDH, and beta-hCG for screening purposes in patients with $\mathrm{XY}$ PGD is lacking. As discussed for XY CGD, positive tumor markers in the setting of a gonadal mass on pre-operative imaging and/or discordant pubertal characteristics would suggest that a staged surgical procedure is necessary [19]. Mutations have been described in SRY [3,16], NR5A1 (9q33) [29,30], DHH (12q13.1) [3], NROB1 (DAX 1) [3,16], and WNT4 [3,16].

Several disorders, in addition to Turner syndrome, are associated with XY PGD. Campomelic dysplasia is a skeletal malformation syndrome caused by mutations in SOX9 $[3,16]$. Denys-Drash syndrome includes mesangial sclerosis of the kidney and Wilms tumor caused by WT1 germline mutations $[3,16]$. Frasier syndrome, also caused by WT1 germline mutations, is associated with $46, \mathrm{XY}$ CGD and involves focal and segmental glomerulosclerosis of the kidney [3,16]. Alpha-thalassemia/X-linked mental retardation syndrome (ATRX) is characterized by mental retardation, often associated with $\alpha$-thalassemia and gonadal abnormalities such as undescended testicles, testicular dysgenesis, and ambiguous external genitalia [3,16,31].

\section{Recommendations}

For patients with suspected XY PGD, we recommend the following for establishing the diagnosis (see Figure 2):

a. Physical examination: including genitourinary exam to assess for clitoromegaly, phallic size, hypospadias, presence of palpable gonads either in the labioscrotal fold or inguinal region and to evaluate the introitus and patency of the vagina and for other dysmorphic features/malformations that may indicate an underlying syndrome.

b. Genetic testing (adapted from Ostrer [3]):

i. Chromosomal analysis, including karyotype and array CGH

ii. FISH for SRY. Patients with Turner's syndrome and a 45,X karyotype require FISH for $S R Y$ to evaluate for cryptic $Y$ mosaicism [32]

iii. If $S R Y$ is present and chromosome analysis and array CGH are normal, consider sequence analysis for $S R Y, N R 5 A 1$, and $D H H$. If these sequences are normal, verify coverage of NROB1 and WNT4 on array CGH testing and if not well covered, consider targeted duplication analysis.

iv. If other syndrome features are noted on examination, specific genetic testing should be sent

1. SOX9 sequencing if patient has findings consistent with campomelic dysplasia

2. ATRX sequencing if patient has evidence of alpha-thalassemia X-linked mental retardation
3. WT1 sequencing if patient has findings consistent with Denys-Drash syndrome

c. Hormonal evaluation

i. Basal LH and FSH

ii. Serum testosterone levels

iii. hCG stimulation test

iv. Anti-Müllerian Hormone

v. Exclude adrenal steroid biosynthesis defects

d. Imaging: pelvic ultrasound or MRI to look for internal genital anatomy and gonad position; may not be able to visualize undescended gonads on imaging.

e. Surgical management: laparoscopy and gonadal biopsy may be indicated. If the patient has a gonadal mass on pre-operative imaging and/or discordant pubertal characteristics, consider serum tumor markers, including AFP, LDH, and beta-hCG, for preoperative planning. If tumor markers are positive, a staged surgical procedure (laparotomy instead of laparoscopy) is indicated.

\section{Evidence quality: low}

Strength of Recommendation: Strong for all categories except section iii of the genetic testing section, and routinely sending serum tumor markers, which are weak recommendations.

\section{Question 2: which patients with $X Y$ gonadal dysgenesis require gonadectomy, and what is the appropriate timing? \\ Evidence}

Thirteen observational studies from 1970-2013 were identified that provided information about indications for performing gonadectomy and/or recommendations regarding timing for performing gonadectomy in patients with XY gonadal dysgenesis [9,20,33-43]. Only studies with more than 10 patients were included for review. We used the GRADE tool to evaluate the quality of the evidence and provide recommendations. The studies are summarized in Table 1.

\section{Complete $X Y$ gonadal dysgenesis ( $X Y$ CGD)}

Several studies specifically address timing of gonadectomy in patients with XY CGD (Swyer syndrome) [20,33,37]. In these studies, the incidence of gonadal malignancy in patients with XY CGD ranged from $37.5 \%-45 \%$. Of those patients with XY CGD who had gonadal malignancy, dysgerminoma was present in $22-66 \%$. The majority of cases of gonadoblastoma or dysgerminoma are discovered at the time the diagnosis of XY CGD is established, which typically occurs in adolescence although cases of malignancy identified in young children have been reported. In the studies reviewed in Table 1, the youngest patient with dysgerminoma was 
Table 1 GRADE evaluation of literature for timing of gonadectomy

\begin{tabular}{|c|c|c|c|c|c|}
\hline Study & $\begin{array}{l}\text { Type of } \\
\text { study }\end{array}$ & Diagnoses & $\begin{array}{l}\text { Location of gonads that show } \\
\text { malignancy: if specified }\end{array}$ & $\begin{array}{l}\text { Conclusions from each study regarding } \\
\text { timing of gonadectomy }\end{array}$ & Design limitations \\
\hline \multirow{5}{*}{$\begin{array}{l}\text { Wunsch, } \\
\text { et al. } 2012 \\
\text { [33] }\end{array}$} & \multirow[t]{5}{*}{$\begin{array}{l}\text { Observational } \\
\text { Cohort study }\end{array}$} & $\begin{array}{l}8 \text { patients with CGD underwent } \\
\text { gonadectomy: }\end{array}$ & $\begin{array}{l}\text { All patients with CGD had } \\
\text { intra-abdominal gonads }\end{array}$ & Early gonadectomy for patients with CGD & $\begin{array}{l}\text { Small sample size, lack of blinding, } \\
\text { lack of allocation concealment }\end{array}$ \\
\hline & & -Ages ranged from $1-25$ years & \multirow{4}{*}{$\begin{array}{l}\text { All patients with PGD had } \\
\text { intra-abdominal streak gonads. }\end{array}$} & \multirow{4}{*}{$\begin{array}{l}\text { For patients with PGD and non-scrotal } \\
\text { gonads, early gonadectomy may be } \\
\text { warranted }\end{array}$} & \\
\hline & & $\begin{array}{l}-3 \text { patients }(37.5 \%) \text { had evidence of in situ } \\
\text { neoplasia (ages } 3,12,18) \text {; }\end{array}$ & & & \\
\hline & & $\begin{array}{l}-2 \text { of these patients also had dysgerminoma. } \\
12 \text { patients with PGD had gonadal tissue } \\
\text { evaluation: }\end{array}$ & & & \\
\hline & & 1 patient (8.3\%) had gonadoblastoma at age 6 & & & \\
\hline \multirow{3}{*}{$\begin{array}{l}\text { Johansen, } \\
\text { et al. } 2012 \\
\text { [34] }\end{array}$} & \multirow{3}{*}{$\begin{array}{l}\text { Observational } \\
\text { Retrospective } \\
\text { study }\end{array}$} & $\begin{array}{l}15 \text { patients with } \mathrm{PGD}(45 \mathrm{X} / 46, \mathrm{XY} \text { and } \\
\text { variants) had gonadal samples for review: }\end{array}$ & $\begin{array}{l}14 \text { year old male had left inguinal } \\
\text { dysgenetic testis with CIS }\end{array}$ & \multirow{3}{*}{$\begin{array}{l}\text { No specific recommendations for timing, } \\
\text { does indicate that CIS originates before } \\
\text { puberty }\end{array}$} & \multirow{3}{*}{$\begin{array}{l}\text { Small sample size, lack of blinding, } \\
\text { lack of allocation concealment, } \\
\text { ascertainment bias }\end{array}$} \\
\hline & & $\begin{array}{l}\text {-3 patients (20\%) had evidence of In situ } \\
\text { Neoplasia: }\end{array}$ & $\begin{array}{l}2 \text { year old male with right } \\
\text { inguinal dysgenetic testis }\end{array}$ & & \\
\hline & & $\begin{array}{l}-2 \text { males (ages } 2 \text { and 14) and } 1 \text { female } \\
\text { (age 4) had CIS }\end{array}$ & $\begin{array}{l}4 \text { year old female with left } \\
\text { inguinal dysgenetic testis }\end{array}$ & & \\
\hline \multirow{4}{*}{$\begin{array}{l}\text { Martinerie, } \\
\text { et al. } 2012 \\
\text { [35] }\end{array}$} & \multirow{4}{*}{$\begin{array}{l}\text { Observational } \\
\text { Retrospective } \\
\text { Study }\end{array}$} & 20 boys with PGD $(45, X / 46, X Y)$ were studied & $\begin{array}{l}13 \text { year old with intra-abdominal } \\
\text { streak gonad }\end{array}$ & $\begin{array}{l}\text { No specific recommendations for timing of } \\
\text { gonadectomy. }\end{array}$ & \multirow[t]{4}{*}{$\begin{array}{l}\text { Small sample size, lack of blinding, } \\
\text { lack of allocation concealment }\end{array}$} \\
\hline & & $\begin{array}{l}-2 \text { patients (10\%) had evidence of } \\
\text { malignancy: }\end{array}$ & \multirow{3}{*}{$\begin{array}{l}23 \text { year old with intrascrotal } \\
\text { dysgenetic testis (inguinal at birth } \\
\text { with orchidopexy at } 9 \text { years } \\
\text { of age). }\end{array}$} & \multirow{3}{*}{$\begin{array}{l}\text { Recommend strict surveillance of gonads } \\
\text { and testicular function in patients with PGD } \\
\text { raised as males }\end{array}$} & \\
\hline & & Dysgerminoma found in a 13 year old male. & & & \\
\hline & & Seminoma found in a 23 year old male. & & & \\
\hline \multirow[t]{2}{*}{$\begin{array}{l}\text { Rocha, et al. } \\
2011 \text { [20] }\end{array}$} & \multirow{2}{*}{$\begin{array}{l}\text { Observational } \\
\text { Retrospective } \\
\text { study }\end{array}$} & $\begin{array}{l}9 \text { patients with XY CGD who had histology } \\
\text { available. }\end{array}$ & \multirow[t]{2}{*}{ Abdominal } & \multirow[t]{2}{*}{ Recommend gonadectomy at diagnosis } & \multirow[t]{2}{*}{$\begin{array}{l}\text { Limited sample size, lack of blinding, } \\
\text { lack of allocation concealment }\end{array}$} \\
\hline & & $\begin{array}{l}\text {-Gonadoblastoma in } 4 \text { patients (44\%) ages } \\
14-17 \text {, Two of which also had dysgerminoma } \\
(22 \%)\end{array}$ & & & \\
\hline \multirow[t]{3}{*}{$\begin{array}{l}\text { Cools, et al. } \\
2011[36]\end{array}$} & \multirow[t]{3}{*}{$\begin{array}{l}\text { Observational } \\
\text { study }\end{array}$} & $\begin{array}{l}\text { Obtained } 84 \text { gonadal samples from } 39 \\
\text { patients with PGD who were } 45, X / 46, X Y \text { : }\end{array}$ & $\begin{array}{l}1 \text { patient with mild undervirilization } \\
\text { had right abdominal gonad with } \\
\text { gonadoblastoma (age not } \\
\text { specified) }\end{array}$ & $\begin{array}{l}\text { In females with PGD, tumor risk is limited } \\
\text { but gonads are not functional, making } \\
\text { gonadectomy the most reasonable option. }\end{array}$ & \multirow[t]{3}{*}{$\begin{array}{l}\text { Small sample size, lack of blinding, } \\
\text { lack of allocation concealment, } \\
\text { selection bias (no gonadal tissue from } \\
\text { undiagnosed } 45, X / 46, X Y \text { males). }\end{array}$} \\
\hline & & $\begin{array}{l}\text {-In Situ Neoplasia found in } 4 \text { different } \\
\text { patients (10.2\%). }\end{array}$ & $\begin{array}{l}1 \text { patient with ambiguous } \\
\text { phenotype had left abdominal } \\
\text { gonad with gonadoblastoma } \\
\text { (age 1) }\end{array}$ & $\begin{array}{l}\text { Malignancy risk in males appears inversely } \\
\text { related to degree of virilization (more } \\
\text { virilized, less risk). }\end{array}$ & \\
\hline & & -3 patients had gonadoblastoma, 1 had CIS. & $\begin{array}{l}1 \text { patient with ambiguous } \\
\text { phenotype had dysgenetic inguinal } \\
\text { testis with gonadoblastoma (age 1) }\end{array}$ & $\begin{array}{l}\text { Low threshold for gonadectomy in males } \\
\text { with ambiguous genitalia. }\end{array}$ & \\
\hline
\end{tabular}


Table 1 GRADE evaluation of literature for timing of gonadectomy (Continued)

\section{Michala, \\ et al. 2008 \\ [37] \\ Retrospective with Swyer syndrome: \\ study \\ $-45 \%$ with germ cell tumors; \\ $-32 \%$ with dysgerminoma (ages 10-31 \\ years) \\ $-14 \%$ with gonadoblastoma (ages 17, 19, and $27 \mathrm{yrs}$ )}

Observational Gonadal histology reviewed in 22 patients

Cools, et al. Observational 60 gonadectomy samples from 43 patients 2006 [14] Retrospective with gonadal dysgenesis (included CGD and $\begin{array}{ll}\text { Retrospective } & \text { with } \\ \text { Study } & \text { PGD): }\end{array}$

$-35 \%$ incidence of germ cell tumors in patients with $G D(n=16)$, ages ranging from 4 months-25 yrs).

-All but 1 patient with malignancy had $Y$ chromosome material.

-Invasive germ cell tumors found in 13\% $(n=6)$

Mazzanti, Observational Identified 14 Turner patients with Yet al. 2005 Study [38] chromosome material:

-12 out of 14 patients consented to gonadectomy:

$33 \%$ of gonadectomized patients had gonadoblastoma (ages 2,7,11, 15 yrs)

The 15 year-old patient also had a immature teratoma, and a endodermal sinus tumor

Slowikowska- Observational Gonadal histology reviewed in 40 cases of Hilczer, et al. Study 2003 [39] gonadal dysgenesis:
1 patient with female phenotype had right abdominal gonad with CIS (age 16)

Abdominal

id not specify gonadal location

$-67.5 \%$ had 46,XY Karyotype and the remainder had numerical and structura abberations of sex chromosomes.

One patient with 46,XY karyotype had seminoma from abdominal gonad (age 17)

CIS present in 14 patients (35\%) with GD

Sex cord-derived tumors including gonadoblastoma nests and unclassified mixed germ

Abdominal
All gonads were located in the abdomen or upper segment of the inguinal canal

For mildly undervirilized males:

prepubertal biopsy and 1 post-pubertal

biopsy

Recommend bilateral gonadectomy as soon as diagnosis is made

study

Gonadal histology revealing undifferentiated Small sample size, lack of blinding gonadal tissue or testicular tissue staining

positive for OCT3/4 on the basal lamina

contains high risk for gonadal tumors and should lead to immediate gonadectomy.

Testicular tissue displaying maturation delay of germ cells can be left in situ, given that its localization allows for adequate

follow-up.

Ovarian tissue can be safely left in place

Streak is not functional, making its preservation controversial

Recommend bilateral gonadectomy for all

Limited sample size, lack of blinding Turner patients with Y chromosome material lack of allocation concealment.

No specific recommendations for timing of gonadectomy mited sample size, lack of blinding ack of allocation concealment 
Table 1 GRADE evaluation of literature for timing of gonadectomy (Continued)

\begin{tabular}{|c|c|c|c|c|c|}
\hline & & $\begin{array}{l}\text { cell-sex cord-stromal tumors were present in } \\
11 \text { patients }(27.5 \%) \text { with GD }\end{array}$ & & & \\
\hline & & $\begin{array}{l}\text { Ages of malignancy ranged from } 7 \text { months } \\
\text { to } 19 \text { years }\end{array}$ & & & \\
\hline \multirow{3}{*}{$\begin{array}{l}\text { Mendes, } \\
\text { et al. } 1999 \\
{[40]}\end{array}$} & \multirow[t]{3}{*}{$\begin{array}{l}\text { Observational } \\
\text { study }\end{array}$} & $\begin{array}{l}36 \text { patients with Turner syndrome were } \\
\text { studied: }\end{array}$ & Abdominal & $\begin{array}{l}\text { Recommend gonadectomy in Turner } \\
\text { Syndrome patients who are } Y \text { positive }\end{array}$ & $\begin{array}{l}\text { Limited sample size, lack of blinding, } \\
\text { lack of allocation concealment }\end{array}$ \\
\hline & & $\begin{array}{l}\text { Two patients were found to be } Y \text { positive } \\
\text { by PCR }\end{array}$ & & & \\
\hline & & $\begin{array}{l}\text { Of the two Y-positive patients, one had } \\
\text { gonadoblastoma (50\%) }\end{array}$ & & & \\
\hline \multirow[t]{3}{*}{$\begin{array}{l}\text { Gourlay, } \\
\text { et al. } 1994 \\
\text { [42] }\end{array}$} & \multirow[t]{3}{*}{$\begin{array}{l}\text { Observational } \\
\text { Retrospective } \\
\text { Study }\end{array}$} & $\begin{array}{l}11 \text { patients with PGD had gonadal tissue for } \\
\text { review: }\end{array}$ & $\begin{array}{l}\text { All but } 1 \text { patient with PGD and } \\
\text { malignancy had abdominal } \\
\text { gonads }\end{array}$ & $\begin{array}{l}\text { Recommend early gonadectomy in all } \\
\text { patients with XY gonadal dysgenesis as } \\
\text { tumors can develop at an early age }\end{array}$ & $\begin{array}{l}\text { Limited sample size, lack of blinding, } \\
\text { lack of allocation concealment }\end{array}$ \\
\hline & & $\begin{array}{l}\text { Six patients (54\%) had germ cell tumors; } \\
\text { ages ranging from } 1 \text { month to } 19 \text { years }\end{array}$ & $\begin{array}{l}1 \text { PGD patient (age 19) with a } \\
\text { seminoma had scrotal gonads }\end{array}$ & & \\
\hline & & $\begin{array}{l}\text { One patient with } 46, X Y \text { CGD had a } \\
\text { gonadoblastoma (age 17) }\end{array}$ & $\begin{array}{l}\text { The patient with CGD had } \\
\text { abdominal gonads }\end{array}$ & & \\
\hline \multirow{4}{*}{$\begin{array}{l}\text { Robboy, } \\
\text { et al. } 1982 \\
{[43]}\end{array}$} & \multirow{4}{*}{$\begin{array}{l}\text { Observational } \\
\text { Retrospective } \\
\text { Study }\end{array}$} & $\begin{array}{l}\text { Obtained gonadal tissue from } 21 \text { patients } \\
\text { with PGD: }\end{array}$ & $\begin{array}{l}53 \text { year old with gonadoblastoma } \\
\text { had abdominal gonads }\end{array}$ & Recommend early gonadectomy & $\begin{array}{l}\text { Limited sample size, lack of blinding, } \\
\text { lack of allocation concealment }\end{array}$ \\
\hline & & $\begin{array}{l}\text {-Three patients (14.2\%) with XY PGD had } \\
\text { malignancy: }\end{array}$ & $\begin{array}{l}\text { One patient had a } \\
\text { gonadoblastoma and seminoma } \\
\text { in a scrotal-inguinal gonad } 15 \\
\text { years after the contralateral testis } \\
\text { was removed (age not specified) }\end{array}$ & & \\
\hline & & $\begin{array}{l}\text { Two patients with XY PGD had } \\
\text { gonadoblastomas and one of these was } \\
\text { overgrown by a seminoma. }\end{array}$ & $\begin{array}{l}2 \text { week old with seminoma had } \\
\text { an abdominal gonad }\end{array}$ & & \\
\hline & & $\begin{array}{l}\text { One patient with XY PGD had seminoma } \\
\text { (age } 2 \text { weeks) }\end{array}$ & & & \\
\hline \multirow[t]{9}{*}{$\begin{array}{l}\text { Scully, et al. } \\
1970[9]\end{array}$} & \multirow{9}{*}{$\begin{array}{l}\text { Observational } \\
\text { Retrospective } \\
\text { Study }\end{array}$} & $\begin{array}{l}\text { Reviewed clinical characteristics of } 74 \text { cases } \\
\text { of gonadoblastoma: }\end{array}$ & Majority were abdominal gonads & Recommend early gonadectomy & $\begin{array}{l}\text { Lack of blinding, lack of allocation } \\
\text { concealment }\end{array}$ \\
\hline & & $\begin{array}{l}25 \text { phenotypic females, } 35 \text { virilized females, } \\
13 \text { phenotypic males. }\end{array}$ & \multirow{8}{*}{$\begin{array}{l}\text { Inguinal gonadoblastomas were } \\
\text { seen in several of the phenotypic } \\
\text { males (exact number not } \\
\text { specified) }\end{array}$} & & \\
\hline & & 43 patients had invasive germinoma & & & \\
\hline & & Ages ranged from 1 to 38 years & & & \\
\hline & & Karyotypes were available in 30/74 patients: & & & \\
\hline & & $57 \%$ had $46, X Y$ karyotypes & & & \\
\hline & & $30 \%$ with $45, X / 46, X Y$ karyotype & & & \\
\hline & & $3 \%$ (1 patient) with $45, \mathrm{X}$ karyotype & & & \\
\hline & & $10 \%$ with other forms of mosaicism & & & \\
\hline
\end{tabular}

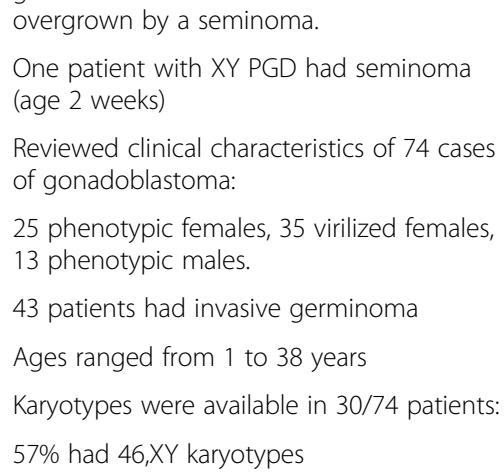


10 years old and the youngest patient with gonadoblastoma was 3 years old [33,37]. The consistent recommendation in the literature is for bilateral gonadectomy to be performed as soon as possible once the diagnosis of $\mathrm{XY}$ CGD (Swyer syndrome) is established, given the high risk of gonadoblastoma with progression to dysgerminoma.

\section{Partial XY gonadal dysgenesis (XY PGD)}

Inconsistency occurs in the literature with respect to timing of gonadectomy in patients with XY PGD. As discussed earlier, XY PGD includes a heterogeneous group of individuals with various degrees of clinical phenotypes and karyotypes, with the most common karyotype being 45,X/46,XY. In earlier literature, early gonadectomy typically was recommended in patients with XY PGD to prevent development of malignancy, although some authors recommended waiting until the age of puberty as the risk of malignancy prior to that time was acceptably low [44]. More recent studies suggest a more individualized and conservative approach in the decision-making process for gonadectomy by taking into account certain factors including location of the gonads (abdominal, inguinal, or scrotal), internal and external phenotype, and sex of rearing. In the studies reviewed in Table 1, most of the cases of malignancy in XY PGD occurred in gonads that were located intra-abdominally, followed by inguinal gonads. Very few cases of intra-scrotal malignancy in patients with XY PGD were reported. As seen in Table 1, all three of the XY PGD patients with malignancy originating from scrotal gonads had a seminoma and were discovered in the second and third decades of life. Given this observation, in patients with XY PGD who are reared as males, many studies recommend surveillance of the gonads with a low-threshold for gonadectomy in those who have nonscrotal gonads, an ambiguous phenotype, or insufficient testicular function. Several authors have recommended regular testicular self-examination and yearly testicular ultrasound in those patients with XY PGD who are reared as males. Testicular biopsy as a means for surveillance has been discussed in the literature and will be reviewed in a following section.

The literature yields no unified approach with respect to timing of gonadectomy in XY PGD patients who are reared as females. Most of the studies addressing $\mathrm{XY}$ PGD patients have looked specifically at 45,X/46,XY mosaic Turner patients. In the studies that are reviewed in Table 1, the risk of malignancy in female patients with $45, \mathrm{X} / 46$, XY karyotype ranged from $2.2-50 \%$, with gonadoblastoma presenting as early as 2 years of age. Although most of the studies recommend early gonadectomy in patients with 45,X/46,XY Turner syndrome, a recent study by Cools, et al., [36] suggested that girls without signs of virilization have a low risk of developing a tumor $(2.2 \%$ with malignancy in their series), so gonadectomy could be postponed in patients who are reluctant to have surgery. This recommendation should be taken with caution, as other studies have shown higher rates of malignancy in this patient population, and there are no established guidelines for monitoring these patients for development of a malignancy if they choose to forego gonadectomy.

\section{Recommendations (See Figure 3)}

a. We recommend that patients with XY CGD (i.e., Swyer syndrome) have bilateral gonadectomy at the time of diagnosis to prevent development of gonadal malignancy.

\section{Evidence quality: low}

Strength of recommendation: strong

b. We recommend that patients with XY PGD with nonscrotal gonads that cannot be repositioned surgically into a scrotal position have bilateral gonadectomy.

\section{Evidence quality: low}

Strength of Recommendation: Strong

c. We suggest that patients with XY PGD with scrotal gonads being reared as males undergo routine monitoring with self-examination for development of malignancy.

\section{Evidence quality: low}

Strength of recommendation: weak

\section{2a: what are differences in risks of malignancy based on diagnoses? \\ Evidence}

The articles in the medical literature that addressed this question are primarily review articles, rendering the GRADE tool not applicable. A recent review by Cools, et al. [14] reported the overall prevalence of germ cell tumors in patients with gonadal dysgenesis as $12 \%$. The prevalence may be underestimated because untreated patients were not included and the presence of a Y chromosome was not an inclusion criterion for many studies. Risks for developing malignancies have been noted based on gonadal dysgenesis etiology (PGD vs. CGD), gonad location, degree of virilization, and certain tumor marker expression in gonadal tissue.

For patients with 46,XY CGD (Swyer syndrome), the risk of developing gonadal malignancy has been reported to be $15-35 \%[14,20,45]$. A recent study by Michala, et al., reported the prevalence of germ cell tumors to be as high as $45 \%$ [37]. Given this high risk of malignancy in patients with $\mathrm{XY}$ CGD, the recommendation to 


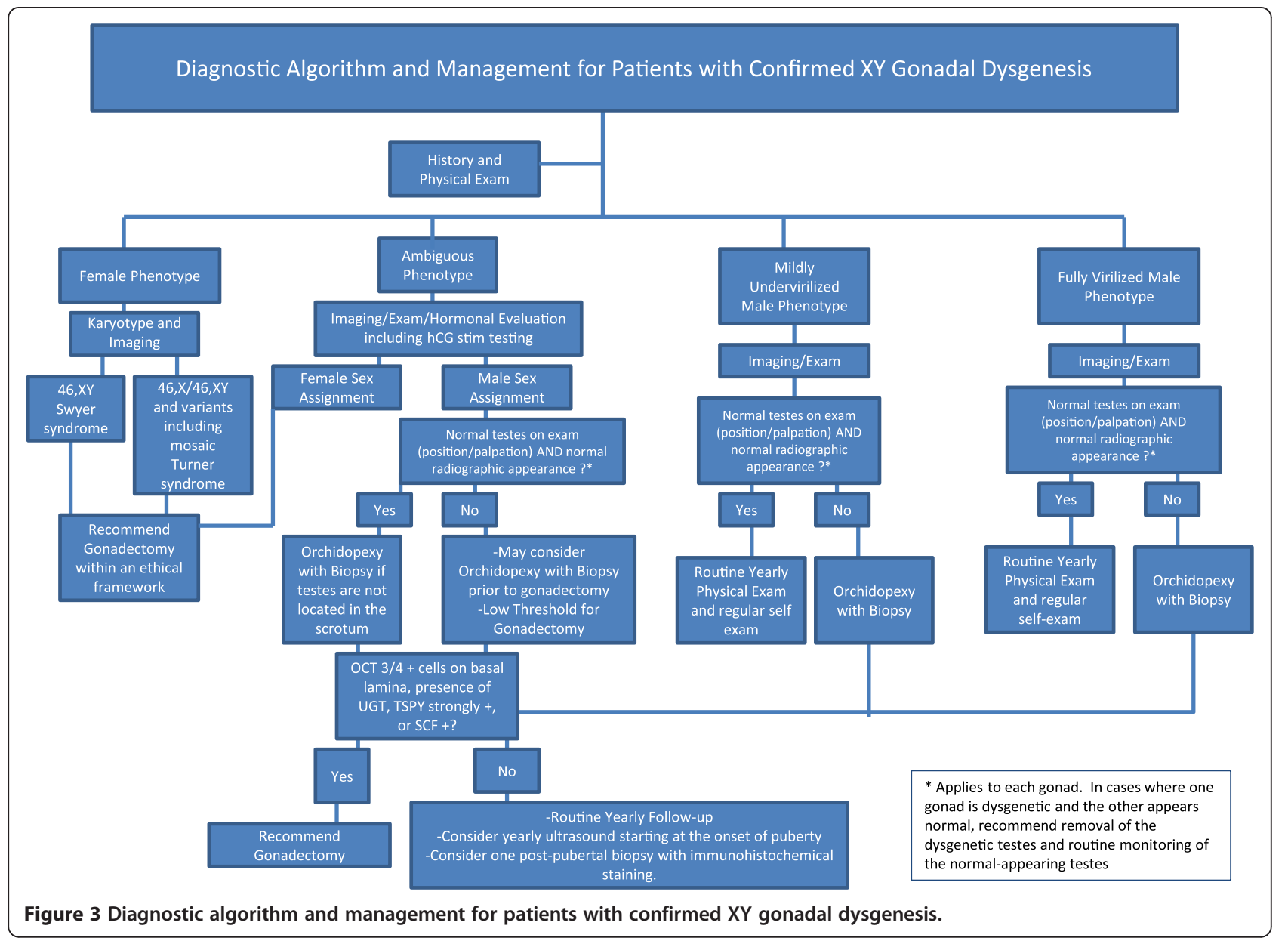

remove gonads at the time of diagnosis is definitely justified.

The risk of developing gonadal malignancy in patients with PGD who have 45,X/46,XY and variants is reported by Cools, et al., as $15-40 \%$ [14]. In patients with mixed gonadal dysgenesis or asymmetrical gonadal differentiation, the estimated tumor prevalence is reported to be approximately $15 \%$, although this figure may be an underestimation [14]. Overall, it is in concordance with the reported malignancy prevalence in the studies summarized in Table 1, with malignancy risk ranging from 8.3-54\% in patients with XY PGD. A series by Gravholt, et al., [46] in 2000 examined the prevalence of gonadoblastoma in Y-positive Turner patients and reported it to be $7-10 \%$, which is lower than reported in other published studies. Although this risk is significant, the authors argued that in situations in which patients or parents do not wish to proceed with gonadectomy, routine monitoring with ultrasound may be used to evaluate for development of malignancy. No evidence supports appropriate frequency of monitoring or suggests that other methods of monitoring, such as laboratory screening, may be more useful in detecting onset of malignancy.
Recent studies have suggested that a correlation exists between the degree of virilization of the external genitalia and gonadal function with subsequent risk for developing a malignancy $[34,36]$. In a study by Cools, et al., [36], the risk of developing a tumor was associated significantly with the clinical phenotype and was found to be greatest (52\%) in those with ambiguous genitalia. The location of the gonads also plays a role in the development of malignancy. In the studies summarized in Table 1, most malignant tumors occurred in gonads in the abdomen; however, several cases of inguinal or scrotal testis showed evidence of either pre-malignant precursor lesions or in situ neoplasia.

Certain immunohistochemical markers (OCT 3/4, c-KIT, TSPY, VASA) have been identified that can be useful in establishing the diagnosis of malignant germ cell tumors $[14,41,45]$. Of these, the combination of OCT $3 / 4$ and TSPY appears to be the most robust in identifying germ cell tumors [41]. OCT $3 / 4$ is a transcription factor that is present during fetal gonadal development but is not normally present postnatally. The location of OCT 3/4-positive cells plays an important role in the risk of developing a malignancy. Cools, et al., showed 
that OCT 3/4-positive cells positioned along the basal lamina of the seminiferous tubule have an increased risk for malignant transformation, whereas OCT 3/4positive cells located more centrally in the seminiferous tubules reflected a delay in maturation and were not associated with an increased risk for malignancy [47]. The TSPY gene (testis-specific protein-Y) is thought to be a main candidate gene involved in development of a gonadoblastoma, and its expression confers an increased risk of malignancy [14].

Many factors must be considered for each individual patient when assessing the risk for developing a malignancy. Table 2, adapted from Plescakova, et al., [45] displays malignancy risk stratification based upon virilization, location of gonads, pathologic features, and immunohistochemical marker findings.

\section{$2 \mathrm{~b}$ : is there a role for gonadal biopsy? Evidence}

Five observational studies were published from 1985 to 2013 that assisted in answering the question concerning gonadal biopsy $[33,36,42,48,49]$. The GRADE tool was used to evaluate the quality of the evidence and to provide recommendations. These studies are summarized in Table 3.

The few studies that address this question in the literature have differing viewpoints on the usefulness of gonadal biopsies in patients with XY gonadal dysgenesis. In several studies, gonadal biopsy is suggested as a useful technique for early diagnosis of germ cell tumors and for follow-up. Additionally, some studies have suggested using laparoscopic gonadal biopsy in cases with unclear diagnoses, allowing for histological examination of gonadal tissue prior to proceeding with gonadectomy [33]. Gonadal biopsy appears to be most useful in monitoring for tumor development in mildly undervirilized males with testes that are either located in the scrotum, or can be brought down surgically into the scrotum. Several recent papers recommend that in patients with XY PGD and a male phenotype, one pre-pubertal biopsy, typically in combination with orchidopexy, and one post-pubertal biopsy with appropriate immunohistochemical staining, including OCT3/4 and TSPY, are warranted to identify patients at risk for malignancy $[36,48]$. The evidence is limited for the usefulness of gonadal biopsy to assess tumor risk in patients with female or ambiguous phenotypes, as their risk for developing gonadal malignancy is high, and the threshold to perform gonadectomy in these patients is low.

Several limitations of gonadal biopsy must be taken into consideration. The retrospective study by Gourlay, et al., [42] noted that gonadal tumors can easily be missed on biopsy because of the many different combinations of cells (testicular, ovarian, fibrous, and tumor) that may be found within the same individual gonad, as well as the limited sampling and sampling errors. Therefore, they reported that gonadal biopsy may be unreliable in excluding the presence of small tumors. Müller, et al., [49] also demonstrated that premalignant lesions may be seen on repeat biopsies from patients with $\mathrm{XY}$ PGD who initially had normal gonadal biopsies. It is important to note that there are no prospective studies that show the usefulness of gonadal biopsy in early detection of malignancy or improving outcomes. Given this, patients with XY PGD who undergo gonadal biopsy should be followed and outcomes should be reported.

\section{Recommendations (see Figure 3)}

a. In patients with $X Y C G D$, gonadal biopsy has no role, as these patients ultimately require gonadectomy to prevent development of a malignancy.

\section{Evidence quality: low}

Strength of recommendation: strong

Table 2 Malignancy risk based upon type of gonadal dysgenesis, location of gonad, gross pathology, and immunohistochemistry

\begin{tabular}{|c|c|c|c|}
\hline & Low risk & Intermediate risk & High risk \\
\hline Degree of virilization & Normally virilized males & Mild undervirilization & Ambiguous genitalia \\
\hline Location of gonad & Scrotal gonad with normal appearance & Inguinal gonad & Abdominal gonad \\
\hline \multirow[t]{4}{*}{ Gross pathology } & -Streak gonad without germ cells & \multirow{4}{*}{$\begin{array}{l}\text { Dysgenetic testicle that is OCT } 3 / 4 \\
\text { positive with intermediate risk criteria }\end{array}$} & \multirow[t]{3}{*}{-Undifferentiated gonadal tissue } \\
\hline & -Ovary & & \\
\hline & - Testicle (OCT 3/4 negative) & & \\
\hline & $\begin{array}{l}\text { - Dysgenetic testicle that is OCT } 3 / 4 \\
\text { negative }\end{array}$ & & $\begin{array}{l}\text {-Dysgenetic testicle that is OCT } 3 / 4 \\
\text { positive with high risk criteria }\end{array}$ \\
\hline Immunohistochemistry & OCT $3 / 4$ negative & $\begin{array}{l}\text { OCT } 3 / 4 \text { positive cells located luminally, } \\
\text { scattered within the whole gonad, TSPY } \\
\text { negative or weakly positive, SCF negative, } \\
\text { age }<1 \text { year. }\end{array}$ & $\begin{array}{l}\text { OCT } 3 / 4 \text { positive cells located in the } \\
\text { basal lamina, focal location, TSPY } \\
\text { strongly positive, SCF positive, } \\
\text { age }>1 \text { year. }\end{array}$ \\
\hline
\end{tabular}


Table 3 GRADE evaluation of literature for use of gonadal biopsy

\begin{tabular}{|c|c|c|c|c|}
\hline Study & Type of study & Summary of findings & $\begin{array}{l}\text { Conclusions from each study regarding use of } \\
\text { gonadal biopsy }\end{array}$ & Design limitations \\
\hline \multirow[t]{3}{*}{$\begin{array}{l}\text { Farrugia, et al. } \\
2013[48]\end{array}$} & \multirow[t]{3}{*}{$\begin{array}{l}\text { Observational } \\
\text { Retrospective study }\end{array}$} & $\begin{array}{l}\text { Histology of } 46 \text { gonads from patients with } 45, X / 46, X Y \text { or } \\
45, X / 47, X Y Y \text { PGD was reviewed. }\end{array}$ & \multirow{3}{*}{$\begin{array}{l}\text { In patients raised as males, where dysgenetic testes are } \\
\text { retained, biopsy at orchidopexy and also post-pubertal with } \\
\text { immunohistochemical staining (OCT } 3 / 4 \text { and TSPY) is } \\
\text { recommended }\end{array}$} & \multirow[t]{3}{*}{$\begin{array}{l}\text { Limited sample size, lack of blinding, } \\
\text { lack of allocation concealment }\end{array}$} \\
\hline & & Does not specify who had biopsy vs. gonadectomy. & & \\
\hline & & No evidence of malignancy in any patient & & \\
\hline \multirow[t]{2}{*}{$\begin{array}{l}\text { Wunsch, et al. } \\
2012 \text { [33] }\end{array}$} & \multirow[t]{2}{*}{$\begin{array}{l}\text { Observational } \\
\text { Cohort study }\end{array}$} & $\begin{array}{l}6 \text { out of } 12 \text { patients with mixed or partial GD had biopsy } \\
\text { to evaluate for malignancy (no gonadectomy). }\end{array}$ & \multirow[t]{2}{*}{$\begin{array}{l}\text { Biopsy can be used for early diagnosis of germ cell tumors } \\
\text { and follow-up. }\end{array}$} & \multirow[t]{2}{*}{$\begin{array}{l}\text { Limited sample size, lack of blinding, } \\
\text { lack of allocation concealment }\end{array}$} \\
\hline & & 1 patient found to have tubular in situ neoplasia. & & \\
\hline \multirow[t]{4}{*}{$\begin{array}{l}\text { Cools, et al. } \\
2011[36]\end{array}$} & \multirow[t]{4}{*}{ Observational Study } & $\begin{array}{l}\text { Histology of } 87 \text { gonads from patients with } 45, X / 46, X Y \text { was } \\
\text { reviewed. }\end{array}$ & \multirow[t]{2}{*}{$\begin{array}{l}\text { For mildly undervirilized males, recommend } 1 \text { prepubertal } \\
\text { biopsy and } 1 \text { post-pubertal biopsy. }\end{array}$} & \multirow[t]{4}{*}{$\begin{array}{l}\text { Limited sample size, lack of blinding, } \\
\text { lack of allocation concealment }\end{array}$} \\
\hline & & Biopsy was done in 15 patients. & & \\
\hline & & $\begin{array}{l}\text { All of the tumors in this series were in situ germ cell } \\
\text { neoplastic lesions, discovered after prophylactic } \\
\text { gonadectomy. }\end{array}$ & \multirow[t]{2}{*}{$\begin{array}{l}\text { In patients with ambiguous genitalia, biopsy can be used } \\
\text { to asses tumor risk, but low threshold for gonadectomy }\end{array}$} & \\
\hline & & $\begin{array}{l}\text { No tumors identifed in the patients who had gonadal } \\
\text { biopsy alone. }\end{array}$ & & \\
\hline \multirow[t]{2}{*}{$\begin{array}{l}\text { Gourlay, et al. } \\
1994 \text { [42] }\end{array}$} & \multirow[t]{2}{*}{$\begin{array}{l}\text { Observational } \\
\text { Retrospective Study }\end{array}$} & $\begin{array}{l}\text { Reviewed pathology from } 21 \text { patients with DSD who } \\
\text { underwent bilateral gonadectomy at time of diagnosis. }\end{array}$ & \multirow[t]{2}{*}{$\begin{array}{l}\text { Gonadal biopsy is unreliable in excluding the presence of } \\
\text { small tumors }\end{array}$} & \multirow[t]{2}{*}{$\begin{array}{l}\text { Limited sample size, lack of blinding, } \\
\text { lack of allocation concealment }\end{array}$} \\
\hline & & $\begin{array}{l}\text { Pathology revealed many different combinations of testis, } \\
\text { ovary, streak, and tumor within the same individual gonad. }\end{array}$ & & \\
\hline \multirow[t]{4}{*}{$\begin{array}{l}\text { Müller, et al. } \\
1985 \text { [49] }\end{array}$} & \multirow[t]{4}{*}{ Observational Study } & $\begin{array}{l}\text { Gonadal tissue from multiple scrotal or labial gonadal } \\
\text { biopsies was studied in } 4 \text { patients with } 45, X / 46, X Y G D \\
\text { (ages } 1 \text { month to } 18 \text { years) }\end{array}$ & \multirow[t]{2}{*}{$\begin{array}{l}\text { Biopsy of scrotal gonads should be done at time of } \\
\text { diagnosis of GD to exclude presence of tumor. }\end{array}$} & \multirow[t]{4}{*}{$\begin{array}{l}\text { Limited sample size, lack of blinding, } \\
\text { lack of allocation concealment }\end{array}$} \\
\hline & & All 4 patients had evidence of CIS: & & \\
\hline & & -2 patients had CIS on initial biopsy & \multirow{2}{*}{$\begin{array}{l}\text { In boys without signs of CIS on initial biopsy, repeat biopsy } \\
\text { should be performed after puberty because prepubertal } \\
\text { CIS lesions may be missed. }\end{array}$} & \\
\hline & & $\begin{array}{l}-2 \text { patients had CIS only on repeat biopsy ( } 8 \text { months and } \\
16 \text { years) }\end{array}$ & & \\
\hline
\end{tabular}


b. In patients with XY PGD who are reared as males with mild undervirilization and gonads that can be repositioned into the scrotum via orchidopexy, we recommend one prepubertal gonadal biopsy at the time orchidopexy is performed and a post-pubertal gonadal biopsy to monitor for malignancy. If both testes are located inguinally, both should be biopsied. If one testis is located inguinally and one is located in the scrotum and appears normal, consider biopsy of both testes. Given this recommendation, clinicians must be aware that, due to limited sampling and sampling error, a normal gonadal biopsy does not completely rule out the presence of a small tumor.

\section{Evidence quality: low}

Strength of recommendation: weak

c. In patients with $X Y P G D$ and are phenotypically normal males with normal appearing testicles that are located in the scrotum, we do not recommend gonadal biopsy but do recommend routine testicular self-examinations.

\section{Evidence quality: low}

Strength of recommendation: weak

\section{2c: what ethical considerations must be taken into account before undertaking gonadectomy? \\ Evidence}

Three articles from 2005 to 2010 provided ethical recommendations for surgical interventions in patients with DSD [50,51]. A summary of these articles is presented in Table 4. Because these are review articles, the GRADE tool was not used. There are no outcome studies that address this question. These articles emphasized that interventions with irreversible consequences such as gonadectomy must be performed based upon a compelling medical indication following thorough diagnostic evaluation. A multidisciplinary team, including specialists in endocrinology, urology, gynecology, psychology, and ethics, should be involved in the decision-making process. The authors noted that the decision for surgical intervention must take into account the best interest of the patient and should also include the family in the decision-making process. If interventions are not urgent, they should be delayed until the child is old enough to make an informed decision. On the other hand, if the decision is made to refrain from an irreversible intervention, this decision should also be justified with appropriate evidence.

Given the irreversible nature of gonadectomy, certain ethical considerations must be taken into account in addition to determining each individual patient's risk for developing a malignancy. Both risks and benefits are involved in either retaining or removing gonads, and a general, beneficence-based principle of intervening only when the benefits are reliably judged to outweigh the risks should be maintained [50-52]. Benefits of undergoing a gonadectomy would include decreasing the risk of developing a gonadal malignancy. In the case of a patient with XY PGD who is assigned a female sex, the function of gonads at puberty may cause unwanted virilization, rendering a gonadectomy psychosocially beneficial. In contradistinction, certain benefits may be associated with retaining the gonad. Surgical procedures can lead to associated morbidity, and for situations with lower risks of development of a malignancy, it may be reasonable to wait until the patient has reached the capacity for developmentally appropriate assent or can legally consent before being subjected to such risk [51,52]. In addition, for patients with XY PGD and a male sex assignment, the gonads may have partially functioning testicular tissue that could be a source of hormone production through puberty and potential fertility. Overall, the decision for performing a gonadectomy must be made on a case-by-case basis based on the best interest of the patient.

\section{Recommendations}

a. The decision for gonadectomy should be made on a case-by-case basis, in conjunction with a multidisciplinary team and the family.

\section{Evidence quality: low}

Strength of recommendation: strong

b. Gonadectomy may be considered only if the benefits clearly outweigh the risks.

\section{Evidence quality: low}

Strength of recommendation: strong

\section{Conclusions}

Using a systematic approach in evaluating the literature allowed us to develop recommendations for the diagnostic work-up, assessment of gonadal malignancy risk, timing of gonadectomy, and ethical considerations that must be incorporated when providing care for patients with XY gonadal dysgenesis. We chose to focus on these particular aspects of gonadal dysgenesis as they can be used to assess the risk of developing a gonadal malignancy and are areas in which no standardized approach has been established. We have provided an algorithm for diagnostic work-up and gonadal malignancy risk stratification based on the existing published evidence in this field. Our review is limited due to the paucity of long-term outcome studies and no randomized controlled studies in the area of $\mathrm{XY}$ gonadal dysgenesis. Although this paucity of information 
Table 4 Summary of literature addressing ethical recommendations for surgical intervention in DSD patients

\begin{tabular}{|c|c|c|c|c|}
\hline Study & $\begin{array}{l}\text { Type of } \\
\text { study }\end{array}$ & Considerations specific to gonadectomy & $\begin{array}{l}\text { Relevant ethical dilemmas/principles } \\
\text { identified }\end{array}$ & Recommendations \\
\hline \multirow[t]{7}{*}{$\begin{array}{l}\text { Gillam, et al. } \\
2010 \text { [51] }\end{array}$} & \multirow[t]{7}{*}{ Review } & Early Gonadectomy: & 1. Psychological issues poorly understood & $\begin{array}{l}\text { 1. Improve understanding physical and psychological } \\
\text { dilemmas facing each patient }\end{array}$ \\
\hline & & 1. Medical indication (i.e. hernia) & 2. No guarantee of adult gender identity & 2. Thorough informed consent process \\
\hline & & 2. Parental concerns about malignancy & \multirow{5}{*}{$\begin{array}{l}\text { 3. Surgical decision making places pressure on } \\
\text { parents, who may be incompletely informed }\end{array}$} & \multirow{5}{*}{$\begin{array}{l}\text { 3. Referral to multi-disciplinary team - and if not } \\
\text { available refrain from any potentially harmful practice } \\
\text { or surgery }\end{array}$} \\
\hline & & $\begin{array}{l}\text { 3. Difficulty accepting phenotype without surgery/improved } \\
\text { psychological outcome }\end{array}$ & & \\
\hline & & Late Gonadectomy - after puberty completed & & \\
\hline & & No Gonadectomy: & & \\
\hline & & 1. Long term follow up required & & \\
\hline \multirow[t]{6}{*}{$\begin{array}{l}\text { Wiesemann, } \\
\text { et al. } 2010 \\
{[50]}\end{array}$} & \multirow[t]{6}{*}{ Review } & \multirow{6}{*}{$\begin{array}{l}\text { "Unless well-being would otherwise be severely impaired, decisions } \\
\text { about removal of organs or structures important to... physical } \\
\text { integrity or sexual identity (such as gonads) should be left up to the } \\
\text { affected persons themselves" }\end{array}$} & $\begin{array}{l}\text { 1. Secrecy within families, lack of informed } \\
\text { consent and adolescent assent }\end{array}$ & $\begin{array}{l}\text { 1. Acknowledge that even a participant child cannot } \\
\text { act in their future self's best interest, only in the current } \\
\text { best interest }\end{array}$ \\
\hline & & & $\begin{array}{l}\text { 2. conflict between the interests of a child } \\
\text { and the interests of the future adult }\end{array}$ & $\begin{array}{l}\text { 2. In the absence of an objective best interest for the } \\
\text { child in managing DSD, parents should play a major } \\
\text { role in decision making, on a case-by-case basis }\end{array}$ \\
\hline & & & $\begin{array}{l}\text { 3. conflict between right to familial privacy } \\
\text { and state's interest in protecting the child }\end{array}$ & $\begin{array}{l}\text { 3. We should not make a sweeping recommendation } \\
\text { on the timing of a surgical intervention in the absence } \\
\text { of medical necessity }\end{array}$ \\
\hline & & & 4. immediacy of health threat & $\begin{array}{l}\text { 4. Involvement of the child at a developmentally } \\
\text { appropriate level }\end{array}$ \\
\hline & & & \multirow[t]{2}{*}{ 5. child's right to dignity and bodily integrity } & $\begin{array}{l}\text { 5. Allowing the adult patient to access all past medical } \\
\text { records }\end{array}$ \\
\hline & & & & $\begin{array}{l}\text { 6. Careful documentation of outcomes for future } \\
\text { information }\end{array}$ \\
\hline \multirow{6}{*}{$\begin{array}{l}\text { Maharaj, } \\
\text { et al. } 2005 \\
\text { [52] }\end{array}$} & \multirow[t]{6}{*}{ Review } & 1.Paper addresses only infants and young children & 1. Minimizing physical risk to child & $\begin{array}{l}\text { 1. Act in the best interests of the child, taking account } \\
\text { wishes of the parents }\end{array}$ \\
\hline & & $\begin{array}{l}\text { 2. Unclear how to decide whether it is worse to be at future risk of } \\
\text { malignancy or risk of distress in the future from gonadectomy }\end{array}$ & 2. Minimizing psychosocial risk to child & $\begin{array}{l}\text { 2. In situations that are complex with no clear best } \\
\text { answer, where future outcomes are difficult to predict, } \\
\text { parents' wishes should be respected }\end{array}$ \\
\hline & & $\begin{array}{l}\text { 3. Fertility potential may be a factor, including presence and } \\
\text { functionality of gonads, or presence/functionality of other } \\
\text { reproductive organs. May conflict with another risk, such as future } \\
\text { malignancy. }\end{array}$ & 3. Preserving potential for fertility & $\begin{array}{l}\text { 3. None of the principles should be considered to } \\
\text { outweigh the others and must be appropriately } \\
\text { balanced }\end{array}$ \\
\hline & & $\begin{array}{l}\text { 4. Acknowledging that there may be medical advances in the future } \\
\text { which could allow fertility even in apparent non-functional gonadal } \\
\text { tissue }\end{array}$ & $\begin{array}{l}\text { 4. Preserving or promoting capacity to have } \\
\text { satisfying sexual relation }\end{array}$ & $\begin{array}{l}\text { 4. Ethical decision-making in this field should be } \\
\text { approached systematically and in a multi-disciplinary } \\
\text { fashion }\end{array}$ \\
\hline & & & 5. Leaving options open for the future & \\
\hline & & & 6. Respecting parents' wishes and beliefs & \\
\hline
\end{tabular}


does contribute to a low quality of evidence available for review, we have found that strong recommendations exist for many of the questions addressed in this paper. Further studies are necessary to assess the risk for developing malignancy and to evaluate various interventions in affected patients. In conclusion, this paper illustrates that patients with XY gonadal dysgenesis require personalized health care and that the decision for performing a gonadectomy should be tailored to each individual patient based on the underlying specific clinical and histopathologic diagnosis and risk for malignancy. Our recommendations contribute important components that augment the diagnostic and management armament employed by physicians who treat patients with these conditions.

\section{Abbreviations}

CGD: Complete gonadal dysgenesis; PGD: Partial gonadal dysgenesis; MGD: Mixed gonadal dysgenesis; CIS: Carcinoma in situ; SCF: Stem cell factor; TSPY: Testis-specific protein-Y; DSD: Disorders of sex development; UGD: Undifferentiated gonadal tissue.

\section{Competing interests}

The authors involved in this paper declare that they have no competing interests.

\section{Author's contributions}

BMC performed the literature review, used the GRADE tool to evaluate the literature, and drafted the manuscript. RM assisted with literature review, helped draft the manuscript, and made key changes to the intellectual content. $J D, L M, R S, E A, B S, D R, S G$, and MJH critically reviewed the manuscript and made key changes with respect to the design and intellectual content. LK was involved in the initial conception and design of the manuscript as well as critical review and key changes to the intellectual content. CM provided the training necessary for composing an evidence-based medicine article, critically appraised the paper and provided key changes to the intellectual content. All authors read and approved the final manuscript.

\section{Author's information}

BMC is a second year pediatric endocrinology fellow at Baylor College of Medicine, Texas Children's Hospital.

RM is a second year pediatric \& adolescent gynecology fellow at Baylor College of Medicine, Texas Children's Hospital.

$J D$ is an associate professor, chief, and fellowship director of pediatric \& adolescent gynecology at Baylor College of Medicine, Texas Children's Hospital.

LM is a professor of medicine and medical ethics, and is the chair of the center for medical ethics and health policy at Baylor College of Medicine. RS is an associate professor of the department of molecular and human genetics at Baylor College of Medicine, genetics residency program director, and medical director of the biochemical genetics laboratory at Baylor College of Medicine.

EA is a genetic counselor in the department of molecular and human genetics at Baylor College of Medicine.

BS is an assistant professor of urology at Baylor College of Medicine, Texas Children's Hospital.

DR is a professor and chief of pediatric urology at Baylor College of Medicine, Texas Children's Hospital.

LK is a professor of pediatric endocrinology \& metabolism at Baylor College of Medicine, Texas Children's Hospital.

SG is an associate professor of pediatric endocrinology \& metabolism at Baylor College of Medicine, Texas Children's Hospital.

$\mathrm{MJH}$ is a professor of pathology at Baylor College of Medicine, Texas Children's Hospital.

$\mathrm{CM}$ is an associate professor in the department of pediatric emergency medicine at Baylor College of Medicine, Texas Children's Hospital. CM is also the director for the Evidence based Outcomes Center and Center for Clinical Effectiveness at Texas Children's Hospital.

\section{Acknowledgements}

The authors are very grateful to Dr. B. Lee Ligon of the Department of Pediatrics, Baylor College of Medicine for her editorial contributions. They also acknowledge Abiola Odejimi, a medical student at Baylor College of Medicine who assisted with the literature search; Janelle Smith from the Evidence Based Outcomes Center at Baylor College of Medicine for her assistance with the GRADE process; and Dr. Jake Kushner, Chief of Pediatric Diabetes and Endocrinology at Baylor College of Medicine for his support of this paper.

\section{Author details}

'Division of Pediatric Endocrinology, Baylor College of Medicine, Texas Children's Hospital, Houston, TX 77030, USA. 'Division of Pediatric and Adolescent Gynecology, Department of Obstetrics and Gynecology, Baylor College of Medicine, Texas Children's Hospital, Houston, TX 77030, USA. ${ }^{3}$ Center for Medical Ethics and Health Policy, Baylor College of Medicine, Texas Children's Hospital, Houston, TX 77030, USA. ${ }^{4}$ Department of Molecular and Human Genetics, Baylor College of Medicine, Texas Children's Hospital, Houston, TX 77030, USA. ${ }^{5}$ Division of Pediatric Urology, Department of Surgery, Baylor College of Medicine, Texas Children's Hospital, Houston, TX 77030, USA. ${ }^{6}$ Department of Pathology, Baylor College of Medicine, Texas Children's Hospital, Houston, TX 77030, USA. 'Evidence-Based Outcomes Center, Baylor College of Medicine, Texas Children's Hospital, Houston, TX 77030, USA.

Received: 27 November 2013 Accepted: 14 March 2014 Published: 14 April 2014

\section{References}

1. Lee PA, Houk CP, Ahmed SF: Consensus statement on management of intersex disorders: international consensus conference on intersex. Pediatrics 2006, 118:e488-e500.

2. MacLaughlin DT, Donahoe PK: Sex determination and differentiation. N Engl $J$ Med 2004, 350:367-378.

3. Ostrer H: 46,XY disorder of Sex development and 46.XY complete gonadal dysgenesis. Seattle: GeneReviewsSeries; 1993.

4. Fallat ME, Donahoe PK: Intersex genetic anomalies with malignant potential. Curr Opin Pediatr 2006, 18:305-311.

5. Giwercman A, Berthelsen JG, Muller J: Screening for carcinoma-in-situ of the testis. Int J Androl 1987, 10:173-180.

6. Skakkebaek NE, Berthelsen JG, Giwercman A: Carcinoma-in-situ of the testis: possible origin from gonocytes and precursor of all types of germ cell tumours except spermatocytoma. Int J Androl 1987, 10:19-28.

7. Verp MS, Simpson JL: Abnormal sexual differentiation and neoplasia. Cancer Genet Cytogenet 1987, 25:191-218.

8. Scully RE: Gonadoblastoma; a gonadal tumor related to the dysgerminoma (seminoma) and capable of sex-hormone production. Cancer 1953, 6:455-463.

9. Scully RE: Gonadoblastoma: a review of 74 cases. Cancer 1970, 25:1340-1356.

10. Hung W, Randolph JG, Chandra R: Gonadoblastoma in dysgenetic testis causing male pseudohermaphroditism in newborn. Urology 1981, 17:584-587.

11. Hart WR, Burkons DM: Germ cell neoplasms arising in gonadoblastomas. Cancer 1979, 43:669-678.

12. Dieckmann KP, Pichlmeier U: Clinical epidemiology of testicular germ cell tumors. World I Urol 2004, 22:2-14.

13. von der Maase $\mathrm{H}$, Rorth $\mathrm{M}$, Walbom-Jorgensen S: Carcinoma in situ of contralateral testis in patients with testicular germ cell cancer: study of 27 cases in 500 patients. Br Med J 1986, 293:1398-1401.

14. Cools M, Drop SL, Wolffenbuttel KP: Germ cell tumors in the intersex gonad: old paths, new directions, moving frontiers. Endocr Rev 2006 27:468-484

15. Atkins $D$, Best $D$, Briss PA: Grading quality of evidence and strength of recommendations. Brittish Medical Journal 2004, 328:1490.

16. Fleming A, Vilain E: The endless quest for sex determination genes. Clin Genet 2005, 67:15-25.

17. Michala L, Creighton SM: The XY female. Best Prac Res Clin Obstet Gynaecol 2010, 24:139-148,

18. Swyer Gl: Male pseudohermaphroditism: a hitherto undescribed form. Brittish Medical Journal 1955, 2:709-712. 
19. Zalel Y, Piura B, Elchalal U: Diagnosis and management of malignant germ cell ovarian tumors in young females. International Journal of Gynaecology and Obstetrics: the official organ of the International Federation of Gynaecology and Obstetrics 1996, 55:1-10.

20. Rocha VB, Guerra-Junior G, Marques-de-Faria AP: Complete gonadal dysgenesis in clinical practice: the 46,XY karyotype accounts for more than one third of cases. Fertil Steril 2011, 96:1431-1434.

21. Cools M, Hoebeke P, Wolffenbuttel KP: Pubertal androgenization and gonadal histology in two 46, XY adolescents with NR5A1 mutations and predominantly female phenotype at birth. European Journal of Endocrinology/European Federation of Endocrine Societies 2012, 166:341-349.

22. Muroya K, Okuyama T, Goishi K: Sex-determining gene(s) on distal 9p: clinical and molecular studies in six cases. J Clin Endocrinol Metab 2000, 85:3094-3100

23. Biason-Lauber A, Konrad D, Meyer M: Ovaries and female phenotype in a girl with 46, XY karyotype and mutations in the CBX2 gene. Am J Hum Genet 2009, 84:658-663.

24. Pearlman A, Loke J, Le Caignec C: Mutations in MAP3K1 cause 46,XY disorders of sex development and implicate a common signal transduction pathway in human testis determination. Am J Hum Genet 2010, 87:898-904.

25. Cools M, Looijenga LH, Wolffenbuttel KP: Disorders of sex development: update on the genetic background, terminology and risk for the development of germ cell tumors. World J Pediatr 2009, 5:93-102.

26. Chang HJ, Clark RD, Bachman H: The phenotype of $45, X / 46, X Y$ mosaicism: an analysis of 92 prenatally diagnosed cases. Am J Hum Genet 1990, 46:156-167.

27. Conte FA, Grumbach MM, Kaplan SL: A diphasic pattern of gonadotropin secretion in patients with the syndrome of gonadal dysgenesis. J Clin Endocrinol Metab 1975, 40:670-674.

28. Ross JL, Loriaux DL, Cutler GB Jr: Developmental changes in neuroendocrine regulation of gonadotropin secretion in gonadal dysgenesis. J Clin Endocrinol Metab 1983, 57:288-293.

29. Kohler B, Lin L, Mazen I: The spectrum of phenotypes associated with mutations in steroidogenic factor 1 (SF-1, NR5A1, Ad4BP) includes severe penoscrotal hypospadias in $46, X Y$ males without adrenal insufficiency. European Journal of Endocrinology/European Federation of Endocrine Societies 2009, 161:237-242.

30. Camats N, Pandey AV, Fernandez-Cancio M: Ten novel mutations in the NR5A1 gene cause disordered sex development in $46, X Y$ and ovarian insufficiency in 46,XX individuals. J Clin Endocrinol Metab 2012, 97:E1294-E1306.

31. Wilkie $\mathrm{AO}$, Zeitlin $\mathrm{HC}$, Lindenbaum RH: Clinical features and molecular analysis of the alpha thalassemia/mental retardation syndromes. II. Cases without detectable abnormality of the alpha globin complex. Am J Hum Genet 1990, 46:1127-1140.

32. Bianco B, Lipay MV, Melaragno Ml: Detection of hidden $\mathrm{Y}$ mosaicism in Turner's syndrome: importance in the prevention of gonadoblastoma. Journal of Pediatric Endocrinology \& Metabolism: JPEM 2006, 19:1113-1117.

33. Wunsch L, Holterhus PM, Wessel L: Patients with disorders of sex development (DSD) at risk of gonadal tumour development: management based on laparoscopic biopsy and molecular diagnosis. BJU international 2012, 110:E958-E965.

34. Lindhardt Johansen $M$, Hagen CP, Rajpert-De Meyts E: 45,X/46,XY mosaicism: phenotypic characteristics, growth, and reproductive function-a retrospective longitudinal study. J Clin Endocrinol Metab 2012, 97:E1540-E1549.

35. Martinerie L, Morel Y, Gay CL: Impaired puberty, fertility, and final stature in $45, X / 46, X Y$ mixed gonadal dysgenetic patients raised as boys. European Journal of Endocrinology / European Federation of Endocrine Societies 2012, 166:687-694.

36. Cools M, Pleskacova J, Stoop H: Gonadal pathology and tumor risk in relation to clinical characteristics in patients with $45, X / 46, X Y$ mosaicism. J Clin Endocrinol Metab 2011, 96:E1171-E1180.

37. Michala L, Goswami D, Creighton SM: Swyer syndrome: presentation and outcomes. BJOG 2008, 115:737-741.

38. Mazzanti L, Cicognani A, Baldazzi L: Gonadoblastoma in Turner syndrome and Y-chromosome-derived material. Am J Med Genet A 2005, 135:150-154.
39. Slowikowska-Hilczer J, Romer TE, Kula K: Neoplastic potential of germ cells in relation to disturbances of gonadal organogenesis and changes in karyotype. J Androl 2003, 24:270-278.

40. Mendes JR, Strufaldi MW, Delcelo R: Y-chromosome identification by PCR and gonadal histopathology in Turner's syndrome without overt Y-mosaicism. Clin Endocrinol (Oxf) 1999, 50:19-26.

41. Cools M, Stoop H, Kersemaekers AM: Gonadoblastoma arising in undifferentiated gonadal tissue within dysgenetic gonads. J Clin Endocrinol Metab 2006, 91:2404-2413.

42. Gourlay WA, Johnson HW, Pantzar JT: Gonadal tumors in disorders of sexual differentiation. Urology 1994, 43:537-540.

43. Robboy SJ, Miller T, Donahoe PK: Dysgenesis of testicular and streak gonads in the syndrome of mixed gonadal dysgenesis: perspective derived from a clinicopathologic analysis of twenty-one cases. Hum Pathol 1982, 13:700-716.

44. Manuel M, Katayama PK, Jones HW Jr: The age of occurrence of gonadal tumors in intersex patients with a Y chromosome. Am J Obstet Gynecol 1976, 124:293-300.

45. Pleskacova J, Hersmus R, Oosterhuis JW: Tumor risk in disorders of sex development. Sex Dev 2010, 4:259-269.

46. Gravholt $\mathrm{CH}$, Fedder J, Naeraa RW: Occurrence of gonadoblastoma in females with Turner syndrome and $\mathrm{Y}$ chromosome material: a population study. J Clin Endocrinol Metab 2000, 85:3199-3202.

47. Cools M, van Aerde K, Kersemaekers AM: Morphological and immunohistochemical differences between gonadal maturation delay and early germ cell neoplasia in patients with undervirilization syndromes. J Clin Endocrinol Metab 2005, 90:5295-5303.

48. Farrugia MK, Sebire NJ, Achermann JC: Clinical and gonadal features and early surgical management of $45, \mathrm{X} / 46, \mathrm{XY}$ and $45, \mathrm{X} / 47, \mathrm{XYY}$ chromosomal mosaicism presenting with genital anomalies. J Pediatr Urol 2013, 9:139-144.

49. Muller J, Skakkebaek NE, Ritzen M: Carcinoma in situ of the testis in children with 45, X/46, XY gonadal dysgenesis. J Pediatr 1985, 106:431-436.

50. Wiesemann C, Ude-Koeller S, Sinnecker GH: Ethical principles and recommendations for the medical management of differences of sex development (DSD)/intersex in children and adolescents. Eur J Pediatr 2010, 169:671-679.

51. Gillam LH, Hewitt JK, Warne GL: Ethical principles for the management of infants with disorders of sex development. Horm Res Paediatr 2010, 74:412-418.

52. Maharaj NR, Dhai A, Wiersma R: Intersex conditions in children and adolescents: surgical, ethical, and legal considerations. J Pediatr Adolesc Gynecol 2005, 18:399-402.

doi:10.1186/1687-9856-2014-4

Cite this article as: McCann-Crosby et al: State of the art review in gonadal dysgenesis: challenges in diagnosis and management. International Journal of Pediatric Endocrinology 2014 2014:4.

\section{Submit your next manuscript to BioMed Central and take full advantage of:}

- Convenient online submission

- Thorough peer review

- No space constraints or color figure charges

- Immediate publication on acceptance

- Inclusion in PubMed, CAS, Scopus and Google Scholar

- Research which is freely available for redistribution 